\title{
Ecological significance of biogenic silica in the East China Sea
}

\author{
S. M. Liu' ${ }^{1, *}$, J. Zhang ${ }^{1,2}$, R. X. Li $^{3}$ \\ ${ }^{1}$ College of Chemistry and Chemical Engineering, Ocean University of China, 5 Yushan Road, Qingdao 266003, \\ PR China \\ ${ }^{2}$ State Key Laboratory of Estuarine and Coastal Research, East China Normal University, 3663 Zhongshan Road North, \\ Shanghai 200062, PR China \\ ${ }^{3}$ First Institute of Oceanography, State Oceanic Administration, Qingdao 266061, PR China
}

\begin{abstract}
Field observations were carried out in the East China Sea (ECS) in October 2000, May 2001 and April-May 2002. Biogenic silica (BSi) in core sediments, sediment traps, and suspended particulate matter (SPM) was measured; silicate profiles in pore waters were examined. The concentration of BSi in SPM was high in coastal areas. The content of BSi in ECS sediments is less than 1\%, as the result of tremendous riverine input of terrigenous weathered materials. For the ECS Shelf, the dissolution of BSi in sediment cores is important to maintain high levels of silicate in the water column, supporting prolific primary production by diatoms. BSi burial efficiencies, that is, the silica accumulation rate divided by the sum of the silica accumulation rate and the benthic silicate flux, are estimated to be 36 to $97 \%$, higher than in the Equatorial Pacific Ocean and higher than the global ocean average. BSi regeneration efficiency, that is, the ratio of BSi vertical flux minus the BSi accumulation rate relative to BSi vertical flux, is ca. $80 \%$ for the ECS. A silica budget was established for the ECS shelf, and the model output shows that major silicate input comes from the Kuroshio, followed by silicate from the riverine inflow and the Taiwan Strait. About $75 \%$ of gross BSi production dissolves in the water column over the ECS Shelf.
\end{abstract}

KEY WORDS: Biogenic silica $\cdot$ Burial $\cdot$ Regeneration $\cdot$ Budget $\cdot$ East China Sea Resale or republication not permitted without written consent of the publisher

\section{INTRODUCTION}

The biogenic silica (BSi) record in marine sediments acts as a potential proxy for oceanic changes and has a close link to the carbon cycle (Rabouille et al. 1997, Pondaven et al. 2000, Ragueneau et al. 2000, Tréguer \& Pondaven 2000, Bárcena et al. 2002). BSi is preferentially transported over organic carbon throughout the water column and preserved in sediments; it has been used to reconstruct past production of surface waters (Nelson et al. 2002, Romero \& Hebbeln 2003). However, lateral advection of water masses, sediment redistribution and spatial variations in the preservation of silica frustules affect the signature produced in the water column and its burial in marine sediments. Because of spatial variations in BSi preservation, and coupling/uncoupling between $\mathrm{Si}$ and $\mathrm{C}$ in marine bio- geochemical cycles, calibration of the BSi proxy in the modern ocean is required, which requires a full understanding of the mechanisms that control the Si cycle (Ragueneau et al. 2000).

In coastal environment, the BSi record in core sediments provides evidence of eutrophication, for example, in the Mississippi Delta (Turner \& Rabalais 1994). It has been shown that the ratio of plant nutrients and availability of silicate control both the silica productivity and the phytoplankton species composition (Nelson \& Goering 1978, Conley et al. 1993). Silicon limitation in marine systems has been examined in a variety of marine environments (e.g. Brzezinski \& Nelson 1989, 1996, Nelson et al. 2001). Benthic regeneration of dissolved silica is known to be an important source in supporting the production of diatoms, e.g. in the Ross Sea (Nelson et al. 1996). Perturbations in the silica cycle 
observed in many freshwater and coastal marine systems may have far-reaching repercussions on the food webs and trophic structure of aquatic systems (Conley et al. 1993). Therefore, there has been an increase in studies focusing on the Si cycle over the last 2 decades (Ragueneau et al. 2000, Schlüter \& Sauter 2000, DeMaster 2002, Nelson et al. 2002); data for the Si cycle in China's seas are scarce, however.

The East China Sea (ECS) consists of a broad continental shelf and the Okinawa Trough, and it receives tremendous river runoff, notably from the Changjiang (Yangtze River). The ECS is characterized by high tidal energy, very high sediment supply, and frequent storm events that produce resuspension of sediments (Huh \& $\mathrm{Su}$ 1999). The Changjiang plume dispersal is primarily southward in winter and northeastward in summer (Lee \& Chao 2003). The Kuroshio flows northeastward along the margin of the continental shelf. Extensive exchange of water and nutrients between the ECS and the Kuroshio occurs across the shelf-break region through upwelling and frontal processes (Liu et al. 2000). The sub-surface Kuroshio waters upwell across the slope, reaching as far as the offshore area of the Changjiang Estuary, known as part of the Taiwan Warm Current, showing important variation in time and space (Lin et al. 1999, Liu et al. 2000). The Taiwan Warm Current is composed of waters from the northward flow through the Taiwan Strait and shelf-intrusion waters from the Kuroshio in the area north of Taiwan. It occupies the southern part of the ECS and has relative low nutrient concentrations as compared to Kuroshio's sub-surface waters and riverine runoff (Gong et al. 1996).

The shelf area of the ECS is considered to be a net sink for atmospheric $\mathrm{CO}_{2}$ (Wang et al. 2000). The Changjiang Estuary and its adjacent coastal environment have frequent harmful algal blooms (HABs) due to tremendous input of nutrients from the land. The number of HABs has increased dramatically since the 1990s. The most important HAB species in this area include Noctiluca scintillans and Skeletonema costatum (Zhu et al. 1997), which can give rise to hypoxia and/or anoxia in marine ecosystems (GEOHAB 2001). Moreover, large-scale (ca. $10^{3}$ to $10^{4} \mathrm{~km}^{2}$ ) blooms of Prorocentrum dentatum have been identified in the region adjacent to the Changjiang Estuary in the period from 2000 to 2003 (Wang \& Huang 2003).

Knowledge of the origin and fate of BSi in ECS is relevant to the understanding of the population dynamics and community function. It was reported that the riverine flux of dissolved silica has decreased, but those of dissolved inorganic nitrogen and phosphate have increased in the Changjiang, leading to decreasing Si:N and $\mathrm{Si}: \mathrm{P}$ ratios in the adjacent coastal waters, with potential silica limitation of diatom growth (Li \& Cheng 2001). The Si:N ratios in the Changjiang may decrease in the near future, which will influence the ecosystem in the adjacent coastal environment after the construction of the Three Gorges Dam is completed (Liu et al. 2003a).

In the present study, BSi was measured in suspended particulate matter (SPM), samples from sediment traps, and sediment samples; dissolved silica was measured in pore waters. This work was conducted to (1) understand the BSi distribution in the ECS; (2) establish the relationships of $\mathrm{BSi}$ with primary production; and (3) evaluate the ecological significance of BSi in the nutrient dynamics of ECS.

\section{MATERIALS AND METHODS}

Sampling. Field observations were carried out in October 2000, May 2001 and April-May 2002. Water samples were taken at 3 depths (surface, intermediate and near-bottom) for BSi and dissolved silicate analyses in 2002. The data for the amount of dissolved silicate in the water column from the 2002 cruise have already been published (Han et al. 2003). SPM was collected by filtering water samples through pre-cleaned and pre-weighed $0.45 \mu \mathrm{m}$ pore-size acetate cellulose filters. Core sediments were carefully collected to avoid resuspension of bottom sediments by a multicorer having 4 sub-tubes with an inner diameter of $9 \mathrm{~cm}$ and a length of $61 \mathrm{~cm}$ at Stns E3, E4 and E6 in 2000, Stns E4, E5 and E6 in 2001, and Stns DB6, DC10 and D34 in 2002 (Fig. 1). The core sediments were sectioned at 0.5 to $5 \mathrm{~cm}$ intervals in nitrogen gas. Samples for the analysis of silicate concentration in the bottom waters were taken from the multi-corer by drawing water from $5 \mathrm{~cm}$ above the undisturbed sedimentwater interface. The pore waters were extracted from sediments by centrifuging at $4000 \mathrm{rpm}(3790 \times \mathrm{g})$ for $15 \mathrm{~min}$ and filtered through pre-cleaned $0.45 \mu \mathrm{m}$ poresize ace-tate cellulose filters. Water content of the sediments was estimated by the change in weight before and after freeze-drying. The deposition flux of biogenic materials was estimated by measurement of $\mathrm{BSi}$, organic carbon and nitrogen from 4 sediment traps set up below the euphotic zone, but above the bottom turbid layer. Each trap was sampled for 1 to $2 \mathrm{~d}$ in the 2002 cruise (Stns T1 to T4; Stn T1: $29^{\circ} 42.107^{\prime} \mathrm{N}$, $122^{\circ} 21.93^{\prime} \mathrm{E}$, Stns T2 to T4: between $30^{\circ} 45.373^{\prime} \mathrm{N}$, $122^{\circ} 25.809^{\prime} \mathrm{E}$ and $30^{\circ} 49.068^{\prime} \mathrm{N}, 122^{\circ} 37.027^{\prime} \mathrm{E}$; depths of deployment: 9, 10, 24 and $11 \mathrm{~m}$ which were 3, 4, 9 and $5 \mathrm{~m}$ above the seabed at Stns T1 to T4, respectively). Each sediment trap was made of polyvinylchloride cylinders, having an opening with a diameter of $14.6 \mathrm{~cm}$ and length of $59 \mathrm{~cm}$, with a polyvinylchloride baffle consisting of cells $1.7 \mathrm{~cm}^{2}$ and $4 \mathrm{~cm}$ deep to reduce turbulence and the unwanted capture of large swimmers. A $450 \mathrm{ml}$ polyethylene sample bottle was 

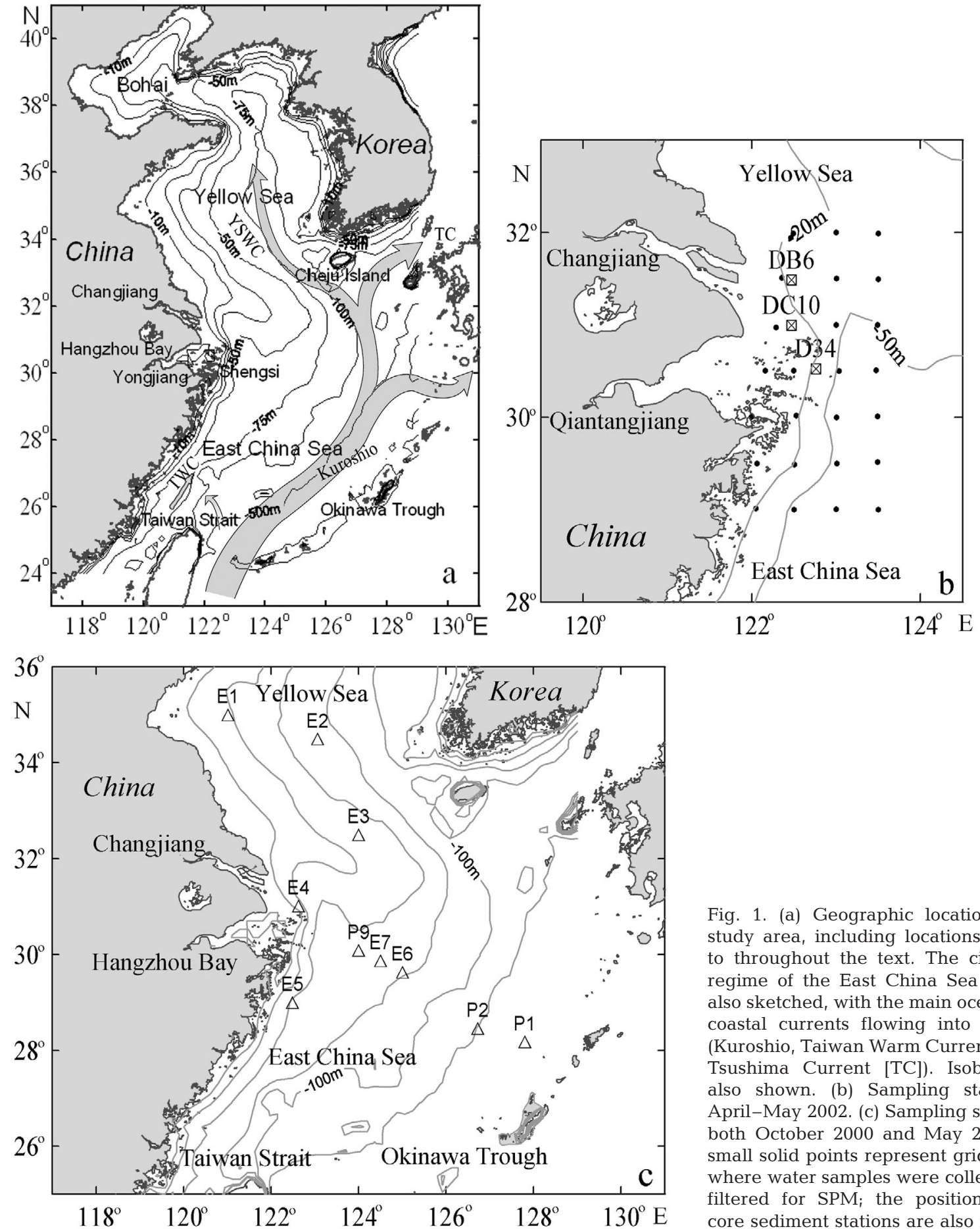

Fig. 1. (a) Geographic location of the study area, including locations referred to throughout the text. The circulation regime of the East China Sea (ECS) is also sketched, with the main oceanic and coastal currents flowing into the area (Kuroshio, Taiwan Warm Current [TWC], Tsushima Current [TC]). Isobaths are also shown. (b) Sampling stations in April-May 2002. (c) Sampling stations in both October 2000 and May 2001. The small solid points represent grid stations where water samples were collected and filtered for SPM; the positions of the core sediment stations are also indicated

attached to the bottom of each cylinder with screw threads. The receiving bottles were filled with filtered seawater and $\mathrm{HgCl}_{2}\left(2.0 \times 10^{-3} \mathrm{v} / \mathrm{v}\right)$ to prevent bacterial decomposition/degradation of settled particles in deployment. On recovery of the traps, particles were collected on pre-weighed $0.45 \mu \mathrm{m}$ poresize acetate cellulose filters and precombusted, pre-weighed What- man GF/F filters. Swimmers which were visible to the naked eye were carefully removed by hand, using a pair of fine-tip tweezers. The filters were freeze-dried.

Sediment-water flux incubation. The exchange flux of nutrients at the sediment-water interface was determined by incubating the core sediments with filtered overlying seawater, and the core-sediment tubes were 
placed in a water bath in darkness (Liu et al. 2003b). The overlying water was continuously bubbled with air to maintain saturation of dissolved oxygen in aerobic conditions. Water samples were taken using plastic syringes from core tubes at 5 to $12 \mathrm{~h}$ intervals over a period of $50 \mathrm{~h}$. The change in composition of the overlying water was used to estimate the net solute exchange across the sediment-water interface.

Chemical analyses. The BSi of particles from sediment traps and bottom sediments was analyzed using the alkaline leaching method of Mortlock \& Froelich (1989), together with the determination of the slope for mineral correction (DeMaster 1981) (cf. Liu et al. 2002). Briefly, BSi was dissolved in $2 \mathrm{M} \mathrm{Na}_{2} \mathrm{CO}_{3}$ at $85^{\circ} \mathrm{C}$. The extracted solution was centrifuged $(3790 \times g)$ and the supernatant was used to determine dissolved silica. The coefficient of variation (CV) for 5 parallel extractions was $1.9 \%$. Four sediment samples provided by D. J. Conley for inter-laboratory comparison (Conley 1998) were measured in this study and compared well with recommended values. BSi in SPM was analyzed by leaching with $5 \% \mathrm{Na}_{2} \mathrm{CO}_{3}$ at $100^{\circ} \mathrm{C}$ for $100 \mathrm{~min}$; $\mathrm{Al}$ measurement was also taken for mineral correction (Kamatani \& Takano 1984). Silicate in the leaching solution was analyzed by the molybdateblue spectrophotometric method (Mortlock \& Froelich 1989), and dissolved aluminum by the fluorimetric method of Ren et al. (2001). The CV for BSi measurement in SPM samples was better than $10 \%$.

The BSi measurement method for sediment traps and core sediments was not used for SPM samples, because the appropriate solid-to-solution ratio for the sediment should be 1 to $5 \mathrm{~g} \mathrm{l}^{-1}$ (i.e. 40 to $200 \mathrm{mg}$ solid to $40 \mathrm{ml}$ solution for $8 \mathrm{~h}$ leaching; Liu et al. 2002). The level for most of the SPM samples, however, was $\leq 30 \mathrm{mg}$. Ragueneau and co-workers performed several alkaline digestion comparisons $(0.2,0.5$ and $1 \mathrm{M} \mathrm{NaOH}, 1,2$ and $5 \% \mathrm{Na}_{2} \mathrm{CO}_{3}$ ) and reached consistent $\mathrm{BSi}$ results (Ragueneau et al. 2001).

The silicate of water samples was analyzed using an autoanalyzer (Model: Skalar SAN ${ }^{\text {plus }}$ ) giving a precision of 1 to $5 \%$. Particulate organic carbon (POC) and nitrogen (PON) were determined for core-sediment samples from Stns DC10, DB6, D34, E4 and the sedimenttrap samples using an Elemental Analyzer (Model: Vario EL III), after removal of carbonates. The precision was $<5$ to $10 \%$, as estimated by repeated analyses.

To compare BSi levels between and within analytical replicates, a 1 -factor analysis of variance (ANOVA) technique was used to process the data at the $\mathrm{p}=$ 0.05 probability level (Morgan 1991).

\section{RESULTS AND DISCUSSION}

\section{BSi in the SPM}

BSi concentrations in 2002 surface waters varied between 0.21 and $2.76 \mu \mathrm{M}$, with an average \pm SD (here and throughout) of $1.3 \pm 0.98 \mu \mathrm{M}$. The highest concentrations of BSi were observed in coastal areas (Fig. 2), which were affected by abundant terrestrial sediment discharge from the Changjiang, as in the Bay of Bengal (Gupta \& Sarma 1997). Although concentrations of BSi in the Changjiang have not been measured, significant concentrations of $\mathrm{BSi}$ - ranging from $2.7 \pm 0.52$ to $74 \pm$ $17.6 \mu \mathrm{M}$, with an average of $28 \mu \mathrm{M}$ - are found in other world rivers, including the Amazon, Connecticut, Danube, Rhine, Mississippi, Lena, and Congo (Conley 1997). BSi concentrations in the Yongjiang, which empties into the Hangzhou Bay, were $1.7 \pm 0.36 \mu \mathrm{M}$ (authors' unpubl. data). Biogenic opal produced by vascular plants, diatoms, and siliceous sponges has been found in soils and terrestrial sediments of continents, with opal ranging from $2 \%$ to more than $5 \%$, except in the Antarctica (Clarke 2003). This can partly explain the high content of BSi near the coast, where SPM was high. Elevated concentrations of BSi in the Changjiang Estuary are also related to the strong vertical mixing that conveys diatom cells upward from the near-bottom and/or sediments back to euphotic surface waters. The Secchi depth was $\sim 1 \mathrm{~m}$ adjacent to the Changjiang Estuary, which means that the euphotic layer is only ca. $3 \mathrm{~m}$ deep (1\% light level corresponds to $2.7 \times$ Secchi depth). Silica production extending to depths greater than that where there is $1 \%$ of light radiation has been reported in most coastal environments (cf. Brzezinski \& Nelson 1989). Abundant nutri-
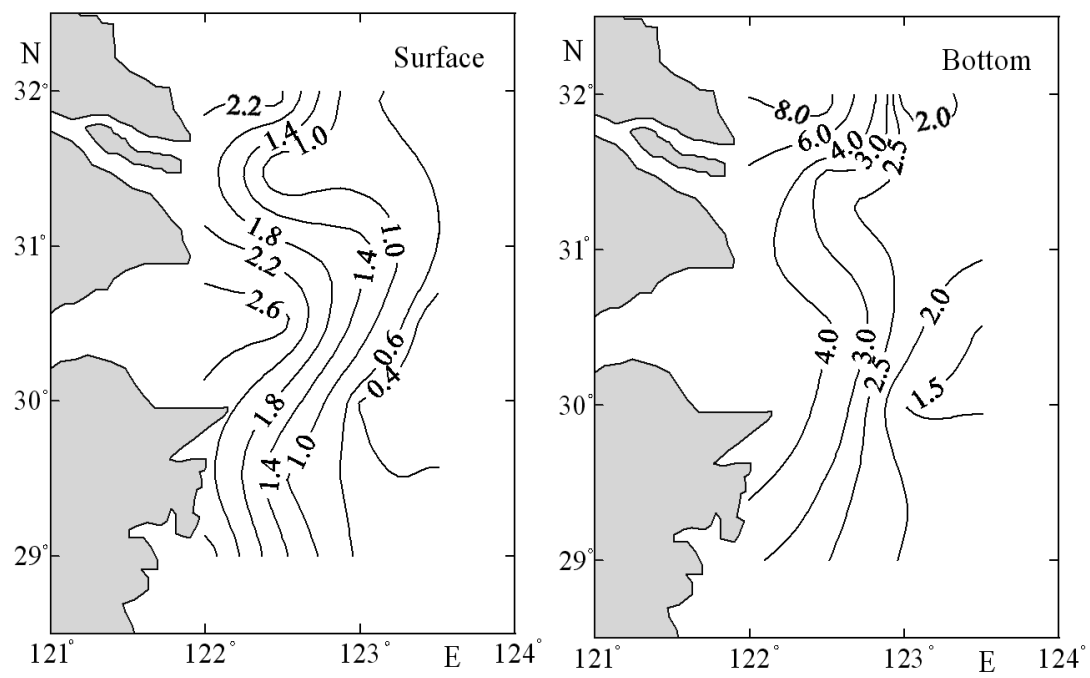

Fig. 2. Horizontal distributions of BSi in surface and near-bottom waters in $2002(\mu \mathrm{M})$ 
ent supply, shallow water depth and strong vertical mixing are prerequisites for the success of large diatoms in estuarine environments (cf. Heiskanen \& Keck 1996). It has been reported that freshwater diatoms contain 10 times more silica per cell volume than marine diatoms (Conley et al. 1989). In addition, diatoms are abundant in the surface sediments of coastal areas, including freshwater species (Kim 1992).

BSi increased with depth, varying from 0.26 to $5.10 \mu \mathrm{M}$, with an average of $1.9 \pm 1.63 \mu \mathrm{M}$, in the intermediate layer and 1.47 to $9.19 \mu \mathrm{M}$, with an average of $3.2 \pm 2.08 \mu \mathrm{M}$, in the bottom waters (Fig. 2). High concentrations of BSi in near-bottom waters are presumably due to high sedimentation rates and resuspension of bottom sediments.

Planktonic diatoms are abundant in the study areas, with Pseudo-nitzschia delicatissma, P. pungens, and Melosira sulcata being the dominant species (Gao et al. 2003, Zhu et al. 2003). Phytoplankton abundance was low $\left(<5 \times 10^{3}\right.$ cells $\left.^{-3}\right)$ in the coastal areas, where the SPM was high $\left(>100 \mathrm{mg} \mathrm{l}^{-1}\right)$, and the dominant species are Paralia sulcata and Coscinodiscus jonesianus (Zhu et al. 2003). The distribution of chlorophyll (chl) a during the 2002 cruise was different from that of $\mathrm{BSi}$, in that the chl a content was high near $123^{\circ} \mathrm{E}$, but low in the surface layer of the coastal areas (Zhou et al. 2003). This is probably caused by the fact that only a small amount of BSi was bound to identifiable diatom cells in the river plume, while a large fraction of the remaining BSi consisted of disintegrated diatom cells.

The concentrations of silicate during the 2002 cruise showed higher values in the coastal areas than offshore areas, especially in surface waters, owing to high freshwater discharge from the Changjiang, and the silicate levels were higher at the near-bottom than in surface waters due to resuspension of sediments (Han et al. 2003). In summary, the distribution of BSi is closely related to that of silicate, and the silica kinetics associated with SPM is a factor affecting the distribution of $\mathrm{BSi}$ in coastal areas. Compared with the BSi content of settling particulate matter at an open-shelf station further offshore in the ECS (e.g. Iseki et al. 2003), the BSi content showed a significant gradient from the coast to the shelf edge and the Okinawa Trough.

\section{BSi in the core sediments and sediment traps}

BSi varied from 0.2 to $0.82 \%$ in core sediments. The variation of BSi at different depths for a given sediment core and the differences of BSi between stations were both significant at the $95 \%$ confidence level, based on the application of ANOVA (Morgan 1991). High concentrations of BSi were observed at Stns DC10, D34, E4 and E5, while low BSi concentrations were found at
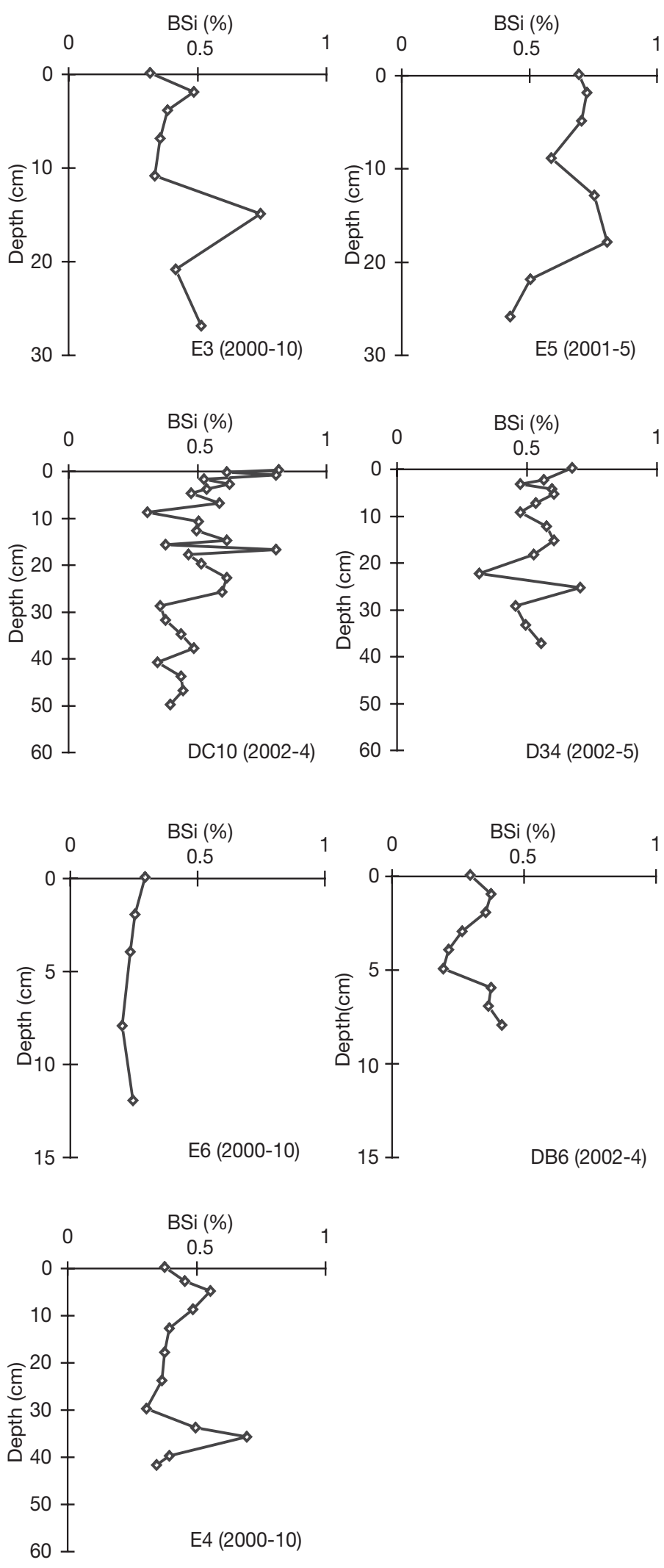

Fig. 3. BSi in core sediments sampled at 7 stations (see Fig. 1) in October 2000, May 2001 and April-May 2002 

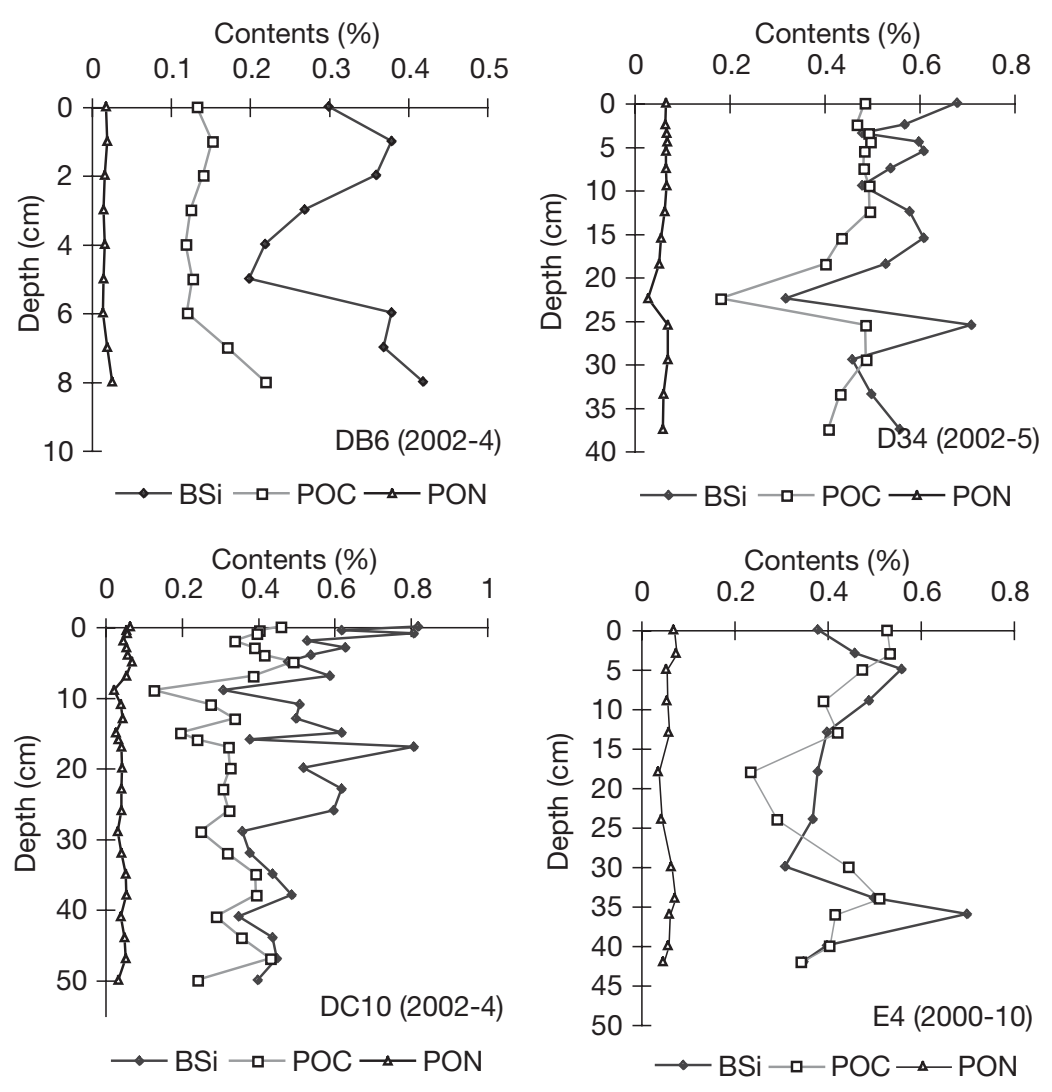

Fig. 4. POC and PON in core sediments sampled at 4 stations (see Fig. 1) in October 2000 and April-May 2002. BSi is shown for comparison

diatom growth and enhance nitrate uptake in coastal areas, but limited increase in silica uptake leads to rapid dissolution of BSi (Boyle 1998). The differences between BSi levels before and after incubation with air and/or nitrogen at Stn DC10 are insignificant at the $95 \%$ confidence level; the change in $\mathrm{BSi}$ was limited for a $50 \mathrm{~h}$ incubation in the coastal environment.

POC and PON ranged from 0.1 to $0.5 \%$ and from 0.02 to $0.08 \%$ in sediments, respectively, with lower values at Stn DB6 relative to other sites (Fig. 4). The difference in POC and PON with depth in each sediment core was significant at the $95 \%$ confidence level. The range of individual atomic ratios was 0.47 to 0.95 for $\mathrm{BSi} / \mathrm{POC}$ and 8.2 to 9.2 for POC/PON, while the average ratios obtained from the slopes of BSi versus POC and POC versus PON - were 0.26 and 8.15 , respectively. The $\mathrm{BSi} / \mathrm{POC}$ atomic ratios in this study are higher than the silicon and carbon production ratio of 0.1 reported in the North Pacific Ocean (Pondaven et al. 1999).

BSi in sediment-trap samples varied between 0.63 and $0.82 \%$. The POC and PON contents were 0.64 to $1.58 \%$ and 0.09 to $0.31 \%$, respectively. $\mathrm{BSi}$,

Stns E3, E6 and DB6 (Fig. 3). Field observations at Stns E3, E6 and DB6 showed the bottom sediments consisted of silt and sand, with considerable shell fragments (e.g. DB6). Accordingly, the pigment content (e.g. chl a plus pheo-pigments) was higher at Stns E4, E5 and DC10 than that at Stns E3, E6 and DB6 (authors' unpubl. data). The variations of BSi within a given core are probably related to changes in primary production and resuspension of bottom sediments. No obvious trend with depth was observed in core sediments, except at Stns DC10, E5 and, to a lesser extent, D34.

The BSi content in ECS sediments was less than $1 \%$, which ranks this area quite low relative to other areas such as the Northwestern Indian Ocean, Southern Ocean and Southern Indian Ocean (Cappellen \& Qiu 1997, Koning et al. 1997, Rabouille et al. 1997). BSi levels in this study are similar to those from the Bohai and Yellow Seas (Liu et al. 2002), and they are comparable to Chesapeake Bay, Bay of Brest and the Northeast Atlantic (D'Elia et al. 1983, Ragueneau et al. 1994, 2001). The low concentrations of BSi can be attributed to the high content of SPM and the shallow euphotic zone. It has been reported that iron may stimulate
POC and PON were higher in particles from sediment traps than in the bottom sediments. The estimated BSi deposition flux ranged from 17.9 to $85.5 \mathrm{mmol} \mathrm{m}^{-2} \mathrm{~d}^{-1}$, with an average of $42 \pm 37.5 \mathrm{mmol}$ $\mathrm{m}^{-2} \mathrm{~d}^{-1}$. This is higher than in the equatorial Pacific Ocean (Ragueneau et al. 2000). The corresponding deposition fluxes of POC and PON were 48.8 to 288 and 6.16 to $35.6 \mathrm{mmol} \mathrm{m} \mathrm{m}^{-2} \mathrm{~d}^{-1}$, with averages of $158 \pm$ 104 and $21 \pm 12.3 \mathrm{mmol} \mathrm{m}^{-2} \mathrm{~d}^{-1}$, respectively. The BSi:POC and POC:PON atomic ratios were 0.22 to 0.45 and 5.97 to 7.94 , respectively, for sediment-trap samples; these values were slightly lower than those in surface sediments. This implies that nitrogen is mineralized fastest in the water column, followed by carbon and then silica. Iseki et al. (2003) investigated the deposition fluxes of $\mathrm{BSi}$ and $\mathrm{POC}$ in this area $\left(31^{\circ} 13^{\prime} \mathrm{N}, 123^{\circ} 05^{\prime} \mathrm{E}\right)$, and they found vertical fluxes of 2.85 to $71.2 \mathrm{mmol} \mathrm{m}^{-2} \mathrm{~d}^{-1}$ for BSi and 15.9 to $271 \mathrm{mmol} \mathrm{m}^{-2} \mathrm{~d}^{-1}$ for POC, similar to the deposition fluxes found in this study. From the data of Iseki et al. (2003), it can be seen that the vertical fluxes of the major biogenic elements (i.e. POC and BSi) decreased from inner shelf to the Okinawa Trough across the ECS. 

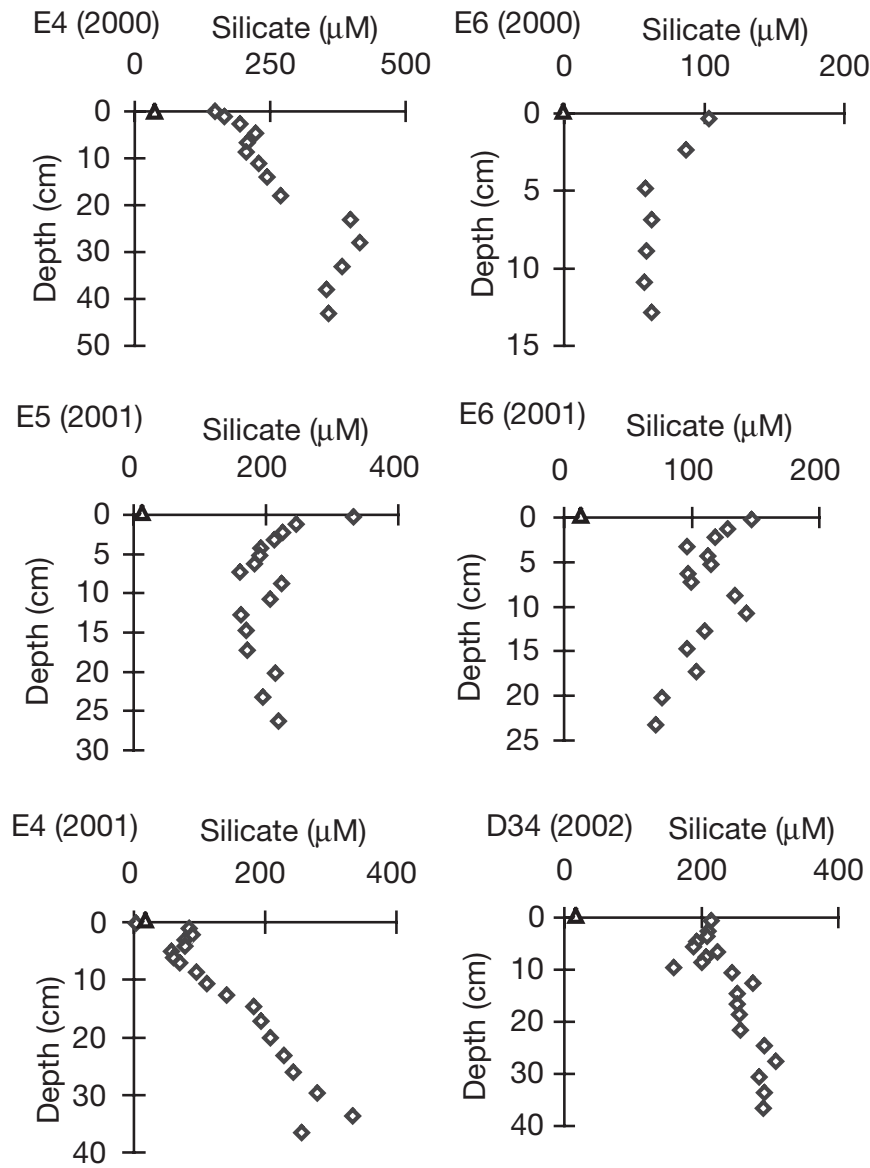

DC10 (2002)

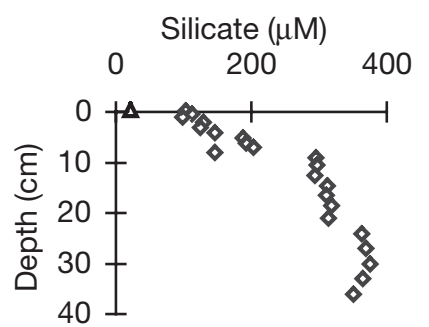

Fig. 5. Sediment pore-water silicate profiles $(\diamond)$ and silicate concentrations in overlying seawater $(\Delta)$ at 7 stations (see Fig. 1) in October 2000, May 2001 and AprilMay 2002. Note differing scales

\section{Regeneration of dissolved silica in sediments}

Pore-water silicate concentrations showed a slight increase with depth except for Stns E5 and E6, where silicate decreased with depth, and bioturbation effects were observed at Stns E4 in 2001 and D34 in 2002 measurements (Fig. 5). The pore-water silicate concentrations at the sediment-water interface indicated diffusion of silicate from the sediment to the overlying seawater.

A first estimate of the benthic diffusion flux of dissolved silica at the sediment-water interface can be obtained by using Fick's first law of diffusion for solutes (Berner 1980):

$$
J_{0}^{*}=-\Phi_{0}(\partial C / \partial x)_{0} D_{\mathrm{s}}
$$

where the subscript 0 refers to the sediment-water interface. $J_{0}{ }^{*}$ is the flux $\left(\mathrm{mmol} \mathrm{m}{ }^{-2} \mathrm{~d}^{-1}\right) ; \Phi$ is the average porosity in the first centimeter of sediment:

$$
\Phi=\left(W_{2}-W_{1}\right) / \rho_{\mathrm{w}} / V_{\mathrm{b}}
$$

where $W_{2}$ is the wet weight of the sediment, $W_{1}$ is the dry weight of the sediment, $\rho_{\mathrm{w}}$ is the density of the water, and $V_{\mathrm{b}}$ is the volume of each interval of sediment; $\partial C / \partial x$ is the pore-water solute gradient; and $D_{\mathrm{s}}$ is the sediment diffusion coefficient, which was estimated from $D$ (Ullman \& Aller 1982):

$$
D_{\mathrm{s}}=D \times \Phi^{m-1}
$$

where $D$ is the molecular diffusion coefficient in free solution (Li \& Gregory 1974) and $m$ is the empirical factor ( $m=2.5$ to 3 at $\Phi \geq 0.7 ; m=2$ at $\Phi<0.7)$. In this study, $m$ was chosen to be 2.5 to 3 at Stns E4, E5 and D34 because $\Phi \geq 0.7$, while $m$ was chosen to be 2 at Stns E6 and DC10, since $\Phi<0.7$. A model based on the diagenetic equations of Berner (1980) and Vanderborght et al. $(1977 \mathrm{a}, \mathrm{b})$ was used to simulate the concentration-depth profiles of dissolved silica. The assumptions include that the main chemical reaction for silicon in sediments is the dissolution of $\mathrm{BSi}$, which is assumed to be of the first order relative to BSi, while compaction water flow, porosity changes, etc., can be ignored. The change in silicate concentration with depth and time in the model is governed by the following steady-state differential equation:

$$
\frac{\partial C}{\partial t}=D_{s} \frac{\partial^{2} C}{\partial x^{2}}-\omega \frac{\partial C}{\partial x}+k_{m}\left(C_{\infty}-C\right)=0
$$

where $k_{m}$ is the rate constant for silicate dissolution, $\omega$ is the sedimentation rate, and $C_{\infty}$ is the asymptotic concentration, as $x \rightarrow \infty$, and can be, but is not necessarily, the concentration of saturation. The sedimentation rates at Stns E4, E6, E5, DB6, DC10 and D34 were obtained by ${ }^{210} \mathrm{~Pb}$ and ${ }^{137} \mathrm{Cs}$ geochronology (DeMaster et al. 1985, Huh \& Su 1999, G. H. Hong pers. comm.). The relative intensity of mixing and accumulation is different on the ECS shelf; accumulation dominates in the inner shelf near the mouth of the Changjiang, while mixing dominates in the middle and outer-shelf areas (DeMaster et al. 1985). Sedimentation rates may be overestimated due to active biological (bioturbation) or physical (tidal currents, storms) mixing in estuarine and shelf sediments, and the ${ }^{210} \mathrm{~Pb}$ method is more prone to error when there is sediment mixing. Nevertheless, sediment accumulation rates based on ${ }^{210} \mathrm{~Pb}$ and ${ }^{137} \mathrm{Cs}$ were used in this study, because we did not have enough information about the seabed environment in the ECS (Huh \& Su 1999, Oguri et al. 2003). The diffusion fluxes of silicate estimated by Eqs. (1) to (4) varied from 0.02 to $1.84 \mathrm{mmol} \mathrm{m}^{-2} \mathrm{~d}^{-1}$, with an average of $0.70 \mathrm{mmol} \mathrm{m}^{-2} \mathrm{~d}^{-1}$ in the study area. The benthic 
Table 1. Exchange fluxes of silicate $\left(\mathrm{mmol} \mathrm{m}^{-2} \mathrm{~d}^{-1}\right)$ at the sediment-water interface calculated using the pore-water silicate gradient (DM) and measured by incubation $(\mathrm{BC})$

\begin{tabular}{|lcccccccc|}
\hline Stn & E4 & E4 & E5 & E6 & E6 & DC10 & D34 & DB6 \\
\hline Cruise & Oct 2000 & May 2001 & May 2001 & Oct 2000 & May 2001 & Apr-May 2002 & Apr-May 2002 & Apr-May 2002 \\
DM & 0.712 & 0.018 & 1.84 & 0.439 & 0.638 & 0.791 & 0.473 & 0.472 \\
BC & 0.464 & 0.546 & 2.63 & & 1.86 & & & 0 \\
\hline
\end{tabular}

silicate fluxes were the highest at Stn E5, where upwelling exists (Table 1).

The benthic silicate fluxes measured by incubating core sediment with in situ seawater are also presented in Table 1, and were higher than the fluxes estimated from pore-water profiles. This emphasizes the physical, chemical and biological contribution to silicate fluxes at the sediment-water interface, similar to that in experiments in the Seto Inland Sea (Srithongouthai et al. 2003).

Benthic silicate fluxes in this study averaged $1.2 \mathrm{mmol} \mathrm{m}^{-2} \mathrm{~d}^{-1}$ in the Changjiang Estuary, which is similar to the result obtained by Aller et al. (1985), who reported silicate fluxes of 0.13 to $13.2 \mathrm{mmol} \mathrm{m} \mathrm{m}^{-2} \mathrm{~d}^{-1}$, with an average of $\sim 2.3 \mathrm{mmol} \mathrm{m} \mathrm{m}^{-2} \mathrm{~d}^{-1}$. The average benthic silicate flux determined in this study demonstrated a pattern of regular increase away from the mouth of the Changjiang. The estimated silicate flux across the sediment-water interface on the ECS Shelf exceeds the total riverine input by 5 -fold (see the discussion, below about silica balance). Similar results were also reported in the Bohai and Yellow Sea (Liu et al. 2002). In Chesapeake Bay, the silicate flux from the sediments exceeds the total riverine input by over 5-fold (D'Elia et al. 1983). The high silicate flux from the bottom sediments appear to maintain high levels of silicate in the mesohaline region, and Si limitation of diatom growth there seems to be relieved (D'Elia et al. 1983). In the Bay of Brest, silicate flux from bottom sediments was the main factor sustaining BSi production in spring bloom and the contribution from the sediment to the BSi production equaled that from watershed drainage (Ragueneau et al. 1994). Although the BSi content in the study region was low relative to other areas of the world, the dissolution of BSi in the sediment profiles can be equally significant and is comparable to the Bohai and Yellow Sea, Chesapeake Bay and the Bay of Brest.

\section{Removal and burial of silica}

Removal of silica from the ocean is regulated by accumulation in sediments. The BSi accumulation rate $\left(\mathrm{BSi}_{\mathrm{ar}}\right)$ in sediments was obtained using the following relation: $\mathrm{BSi}_{\mathrm{ar}}=\mathrm{BSi} \times \omega$, where $\omega$ is the sediment-mass accumulation rate and BSi is the BSi content in the sed- iment. For sites where the mass accumulation rate was not available in this study, w was estimated using the relation $\omega=S \times(1-\Phi) \times \rho$, where $S$ is the linear sediment accumulation rate, $\Phi$ is the average porosity and $r$ is the density of sediment solids (Ingall \& Jahnke 1994). A density of 2.65 was used for all sediments. The $\mathrm{BSi}$ accumulation rates were 0.18 to $11.6 \mathrm{~mol} \mathrm{~m}^{-2} \mathrm{yr}^{-1}$ in the study region, displaying higher values in estuarine and upwelling areas, and lower values at Stns E3, E6 and DB6 further offshore, similar to the distribution of BSi in the sediments.

The BSi burial efficiency, that is, the silica accumulation rate divided by the sum of the silica accumulation rate and the benthic silicate flux, was calculated to range between $36 \%$ at Stn E6 and $97 \%$ at Stn DC10, adjacent to the Changjiang Estuary. These values were higher than those in the Equatorial Pacific Ocean (6.4\%) (Ragueneau et al. 2001), the global ocean average ( 20\%) (Tréguer et al. 1995) and most coastal environments (1.9 to $17.1 \%$ ) (DeMaster et al. 1996, Koning et al. 1997, Rabouille et al. 1997, Schlüter et al. 1998), but are comparable with those in the Polar Front Zone of the Southern Ocean and the Inner Ross Sea (33.0 and $58.1 \%$, respectively; Ragueneau et al. 2001). This is presumably due to high sediment accumulation rates. The ECS low-BSi content and high silica burial efficiency are closely related to sediments of terrigenous origin.

Regeneration of Si in the water column of the investigation area was also evaluated. Sediment-trap studies showed that the vertical fluxes of BSi were $42 \pm$ $37.5 \mathrm{mmol} \mathrm{m}^{-2} \mathrm{~d}^{-1}$. The average Si regeneration efficiency, that is, the ratio of BSi vertical flux minus BSi accumulation rate relative to BSi vertical flux, was calculated to be ca $80 \%$. It appears that most of the silica regenerated in the water column.

\section{Silica balance for the ECS Shelf}

$$
\text { Inputs of silicate }
$$

The main land-source input to the ECS is the Changjiang. Part of the discharge from Changjiang is carried into the Yellow Sea, especially in summer, when the Changjiang plume reaches Cheju Island. 


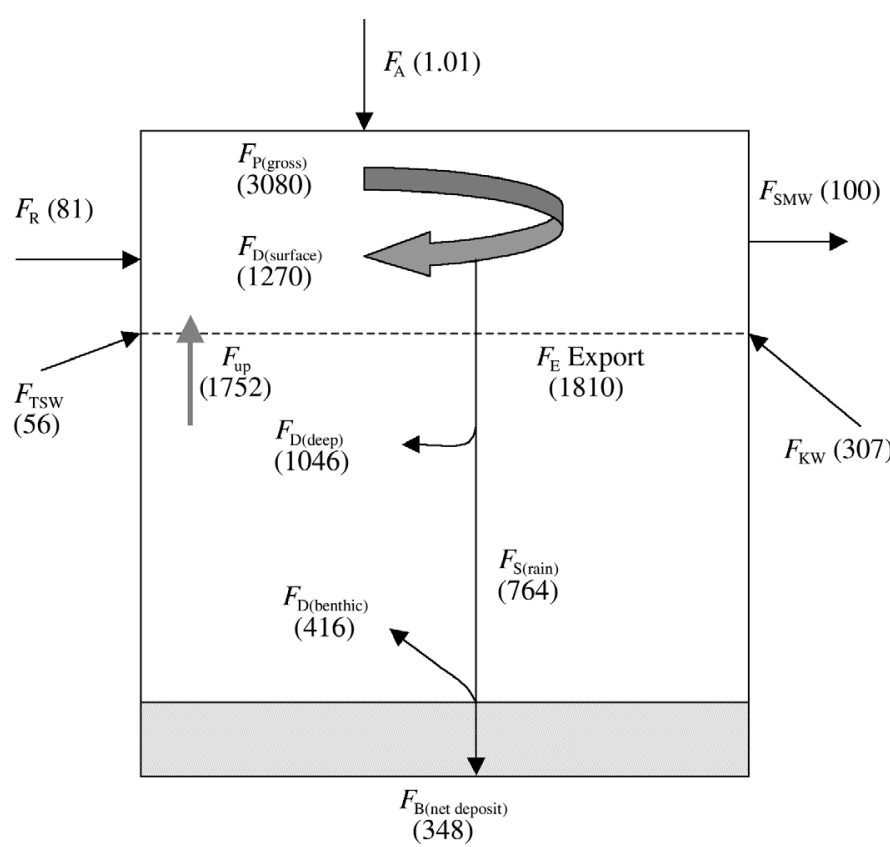

Fig. 6. Biogeochemical cycle of Si on the ECS shelf. All fluxes are in $\times 10^{9} \mathrm{~mol} \mathrm{yr}^{-1}$. River inputs, $F_{\mathrm{R} i}$ atmospheric deposition, $F_{\mathrm{A} i}$ net deposition of $\mathrm{BSi}$ in sediments, $F_{\mathrm{B} i} \mathrm{BSi}$ gross production, $F_{\mathrm{P}}$ (gross); silicate flux recycled in the surface layer, $F_{\mathrm{D}}$ (surface); BSi flux exported toward the deep layer, $F_{\mathrm{E} ;}$ silicate flux recycled in the deep layer, $F_{\mathrm{D}}($ deep); silicate flux transferred from the deep layer to the surface layer, $F_{\text {upi }}$ silicate flux at the sediment-water interface, $F_{\mathrm{D}}$ (benthic); $\mathrm{BSi}$ flux that reaches the sediment-water interface, $F_{\mathrm{S}}(\mathrm{rain})$; silicate input through the Taiwan Strait, $F_{\mathrm{TSW}}$, and Kuroshio water, $F_{\mathrm{KW}}$; offshore transport of silicate, $F_{\mathrm{SMW}}$. The latter 3 items $\left(F_{\mathrm{TSW}}, F_{\mathrm{KW}}\right.$ and $\left.F_{\mathrm{SMW}}\right)$ were taken from Chen \& Wang (1999)

The annual freshwater discharge into the ECS is $86 \%$ (i.e. $794.8 \times 10^{9} \mathrm{~m}^{3}$ ) of the Changjiang runoff, with a silicate discharge of $81 \times 10^{9} \mathrm{~mol} \mathrm{yr}^{-1}$ to the $\operatorname{ECS}\left(F_{\mathrm{R}}\right)$ based on a previous investigation (cf. Liu et al. 2003c) (Fig. 6).

Rainwater and aerosol samples were collected on Shengsi Island, located in the ECS, over a period of $3 \mathrm{yr}$ from May 2000 to April 2003. Total deposition fluxes of silicate based on data for dry (i.e. aerosol) and wet (i.e. rain) depositions were $1.01 \pm 0.61 \times 10^{9} \mathrm{~mol} \mathrm{yr}^{-1}$ (authors' unpubl. data) (Fig. 6).

In the exchange between the ECS and the Kuroshio, the Kuroshio Surface Water (KSW), Kuroshio Subsurface Water (KSSW), and Kuroshio Intermediate Water (KIW) have net onshore transport, while Shelf Mixed Water (SMW) has net offshore transport, because net precipitation and freshwater discharge from rivers exceed evaporation. In addition, there is silicate input through the Taiwan Strait (TSW) (Chen \& Wang 1999). The silicate input was estimated to be $22.3 \times 10^{9} \mathrm{~mol}$ $\mathrm{yr}^{-1}$ from the KSW, $47.3 \times 10^{9} \mathrm{~mol} \mathrm{yr}^{-1}$ from the KSSW, and $237 \times 10^{9} \mathrm{~mol} \mathrm{yr}^{-1}$ from the KIW, with a total input flux of $306.6 \times 10^{9} \mathrm{~mol} \mathrm{yr}^{-1}$ from Kuroshio Water $\left(F_{\mathrm{KW}}\right)$. The silicate input flux was $56 \times 10^{9} \mathrm{~mol} \mathrm{yr}^{-1}$ from the TSW ( $F_{\text {TSW }}$ ) (Chen \& Wang 1999). In contrast, the silicate offshore transport was $100.4 \times 10^{9} \mathrm{~mol} \mathrm{yr}^{-1}\left(F_{\mathrm{SMW}}\right)$ on the basis of the data of silicate concentrations in SMW from Chen \& Wang (1999) and the revised water discharge of SMW found in this study (Fig. 6).

\section{Production of BSi}

Silicate is required by planktonic organisms to grow (e.g. diatoms), and a significant amount of BSi is remobilized by dissolution of silica cells. Production of BSi was estimated by a combination of factors: ${ }^{14} \mathrm{C}$ primary production, the relative contribution of diatoms, and $\mathrm{Si} / \mathrm{C}$ ratios. However, use of measured $\mathrm{Si} / \mathrm{C}$ ratios for natural particle assemblages to transform ${ }^{14} \mathrm{C}$ productivity data into BSi productions is subject to uncertainties (Tréguer et al. 1995). Average primary production in the ECS was $9.0 \pm 3.9$ in winter, $9.3 \pm 4.8$ in spring, $15.7 \pm 9.6$ in summer and $11.3 \pm 4.7 \mathrm{~mol} \mathrm{C} \mathrm{m}^{-2} \mathrm{yr}^{-1}$ in fall, with an annual mean primary productivity of $12.1 \pm 5.7 \mathrm{~mol} \mathrm{~m}^{-2} \mathrm{yr}^{-1}$ (Gong et al. 2003). Estimation of a representative $\mathrm{BSi} / \mathrm{POC}$ ratio for diatoms in natural environments is difficult; diatoms growing in nutrientreplete conditions show a reasonably constant $\mathrm{BSi}$ / POC atomic ratio of $0.13 \pm 0.05$, but in nutrient-poor conditions large variations of the $\mathrm{BSi} / \mathrm{POC}$ ratio can occur, both in oceanic and coastal areas. The BSi/POC atomic ratio in settling particles in this study was 0.22 to 0.45 , and the $\mathrm{BSi} / \mathrm{POC}$ atomic ratio in settling particles was 0.12 to 1.4 on the ECS Shelf (Iseki et al. 2003). The average BSi/POC atomic ratio was hence estimated to be 0.48 . Therefore, the annual BSi production on the ECS Shelf was $3.1 \pm 0.6 \times 10^{12} \mathrm{~mol} \mathrm{yr}^{-1}$, given a surface area of ca. $53 \times 10^{4} \mathrm{~km}^{2}$ over the shelf region of water depth <200 m (Fig. 6).

\section{Silica recycling in sediments and silica budget}

Based on the above discussions, the BSi deposition flux below the euphotic zone determined by this study was 17.9 to $85.5 \mathrm{mmol} \mathrm{m}^{-2} \mathrm{~d}^{-1}$, with an average of $42 \pm$ $37.5 \mathrm{mmol} \mathrm{m}^{-2} \mathrm{~d}^{-1}$. The average BSi deposition flux in the upper water column over the whole ECS Shelf was estimated to be $9.4 \pm 10.1 \mathrm{mmol} \mathrm{m}^{-2} \mathrm{~d}^{-1}$, including the data from Iseki et al. (2003) and this study. The annual flux of BSi exported toward the deep reservoir $\left(F_{\mathrm{E}}\right)$ on the ECS Shelf was determined to be $1.8 \pm 1.95 \times$

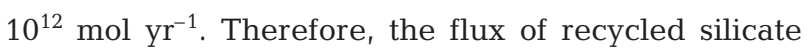
that occurred in the surface layer $\left[F_{\mathrm{D}}\right.$ (surface) $]$ was $1.27 \times 10^{12} \mathrm{~mol} \mathrm{yr}^{-1}$, accounting for $41 \%$ of BSi production (Fig. 6). 
The distribution of surface-sediment types over the ECS Shelf is patchy, consisting of muddy silt at the inner and mid-shelf to muddy sand at the shelf edge. By using data for in situ incubations and pore-water profiles, the sediment-to-water exchange flux over the entire shelf $\left[F_{\mathrm{D}}(\right.$ benthic) $]$ was estimated to be $0.416 \times$ $10^{12} \mathrm{~mol} \mathrm{yr}^{-1}$. The $\mathrm{BSi}$ accumulation rate $\left[F_{\mathrm{B}}\right.$ (net deposit)] on the ECS Shelf was estimated to be $0.348 \times$

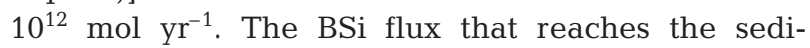
ment-water interface $\left[F_{\mathrm{S}}(\right.$ rain) $]$ was $0.764 \times 10^{12} \mathrm{~mol}$ $\mathrm{yr}^{-1}$, and the silicate flux recycled in the deep reservoir $\left[F_{\mathrm{D}}(\right.$ deep $\left.)\right]$ was $1.05 \times 10^{12} \mathrm{~mol} \mathrm{yr}^{-1}$. Based on heat balance, the upper layer was supposed to be $15 \mathrm{~m}$ and the lower layer $60 \mathrm{~m}$ ( $\mathrm{H}$. Wei pers. commun.), given an average depth of $75 \mathrm{~m}$ on the ECS Shelf. The silicate flux transported from the deep layer to the surface layer $\left(F_{\text {up }}\right.$ ) was calculated to be $1.752 \times 10^{12} \mathrm{~mol} \mathrm{yr}^{-1}$, by assuming the silicate flux from TSW and the Kuroshio was well distributed vertically (Fig. 6). The input of benthic silicate flux accounts for $54 \%$ of the BSi that reaches the sediment-water interface, and the silicate flux recycled in the deep reservoir $\left[F_{\mathrm{D}}(\right.$ deep $\left.)\right]$ accounts for $58 \%$ of the BSi flux exported toward the deep reservoir $\left(F_{\mathrm{E}}\right)$. The removal of silica is mainly by $\mathrm{BSi}$ accumulation in sediment, which accounts for $78 \%$ of the total output.

Considering all input budgets of silicate into the ECS, benthic silicate flux $\left[F_{\mathrm{D}}(\right.$ benthic) $]$ alone accounts for $48 \%$, followed by the Kuroshio onshore transport, accounting for ca $36 \%$, then the riverine input $\left(F_{\mathrm{R}}\right)$, representing $9 \%$; the input through the TSW $\left(F_{\mathrm{TSW}}\right)$ accounts for the remaining $7 \%$.

\section{SUMMARY AND CONCLUSIONS}

Alterations in the concentrations and composition of nutrient loads from land sources have been correlated with changes in phytoplankton species in coastal environments, which affects whole ecosystems in the food web - which in turn represents a significant and expanding threat to human health. An understanding of the mechanisms regulating BSi production and the fate of BSi can help solve this problem, in relation to phytoplankton species composition.

In the ECS, high concentrations of BSi in SPM were observed in coastal areas in the region affected by freshwater discharge, with abundant sediment load from the Changjiang, similar to the Bay of Bengal. The concentrations of BSi increased with water depth due to a high deposition rate and resuspension of bottom sediments. The BSi content in sediments of the ECS were less than $1 \%$, owing to a high content of SPM with a shallow euphotic depth, similar to the Bohai and Yellow Sea and comparable to Chesapeake Bay, the
Bay of Brest and the NE Atlantic. Although the BSi content in the study region is generally low compared with most areas of the world ocean, the dissolution of $\mathrm{BSi}$ in the sediments is active - maintaining high levels of silicate in the water column on the ECS Shelf and supporting important primary production for diatoms. The BSi burial efficiency was estimated to be between 36 and $97 \%$, which is higher than the Equatorial Pacific Ocean and the global ocean average due to high sediment accumulation rates and an elevated amount of SPM from the Changjiang. The BSi regeneration efficiency was calculated to be ca. $80 \%$.

A silica budget was described for the ECS Shelf. The major contribution of silicate input comes from the Kuroshio Water, followed by the Changjiang and Taiwan Strait Water. The inputs are balanced essentially by the net outputs of BSi into bottom sediments. About $75 \%$ of gross BSi production dissolves in the water column. Finally, $11 \%$ of BSi production accumulates in sediments.

Acknowledgements. The authors would like to thank Xi Wen Ye, Xiao Na Li and Ying Fei Zhao for their assistance in sample preparation and analysis. We are indebted to Drs. Hao Wei, Xiu Rong Yin, Jian Bin Li, Xing Liu, Jing Ying Li, Hong Tao Chen, Kui Xuan Lin, Guo Shen Zhang and crews of RV 'Dong Fang Hong 2' and 'Hai Jian 47' for their assistance in field and laboratory work, and the facilities for POC/N determination by SKLEC/ECNU. Prof. O. Kinne and 3 anonymous reviewers of MEPS are thanked for their critical comments and suggestions, which improved the original manuscript. We are grateful to Ms. Janice Willson for her English-language editorial work. This study was funded by the Ministry of Science \& Technology of the People's Republic of China (Grant nos. 2001CB409703 and G1999043705) and the Natural Sciences Foundation of China (Grant no. 40206017).

\section{LITERATURE CITED}

Aller RC, Mackin JE, Ullman WJ, Wang C, Tsai S, Jin J, Sui Y, Hong J (1985) Early chemical diagenesis, sediment-water exchange, and storage of reactive organic matter near the mouth of the Changjiang, East China Sea. Cont Shelf Res $4: 227-251$

Bárcena MA, Isla E, Plaza A, Flores JA, Sierro FJ, Masqué P, Sanchez-Cabeza JA, Palanques A (2002) Bioaccumulation record and paleoclimatic significance in the Western Bransfield Strait: the last 2000 years. Deep-Sea Res II 49:935-950

Berner RA (1980) Early diagenesis: a theoretical approach. Princeton University Press, Princeton, NJ

Boyle E (1998) Pumping iron makes thinner diatoms. Nature 393:733-734

Brzezinski MA, Nelson DM (1989) Seasonal changes in the silicon cycle within a Gulf Stream warm-core ring. DeepSea Res 36:1009-1030

Brzezinski MA, Nelson DM (1996) Chronic substrate limitation of silica production in the Sargasso Sea. Deep-Sea Res II 43:437-453

Cappellen PV, Qiu L (1997) Biogenic silica dissolution in sediments of the Southern Ocean. I. Solubility. Deep-Sea Res II 44:1109-1128 
Chen CTA, Wang SL (1999) Carbon, alkalinity and nutrient budgets on the East China Sea continental shelf. J Geophys Res 104(C9):20675-20686

Clarke J (2003) The occurrence and significance of biogenic opal in the regolith. Earth Sci Rev 60:175-194

Conley DJ (1997) Riverine contribution of biogenic silica to the oceanic silica budget. Limnol Oceanogr 42:774-777

Conley DJ (1998) An interlaboratory comparison for the measurement of biogenic silica in sediments. Mar Chem 63: 39-48

Conley DJ, Kilham SS, Theriot E (1989) Differences in silica content between marine and freshwater diatoms. Limnol Oceanogr 34:205-213

Conley DJ, Schelske CL, Stoermer EF (1993) Modification of the biogeochemical cycle of silica with eutrophication. Mar Ecol Prog Ser 101:179-192

D'Elia CF, Nelson DM, Boynton WR (1983) Chesapeake Bay nutrient and plankton dynamics: III. The annual cycle of dissolved silicon. Geochim Cosmochim Acta 47: 1945-1955

DeMaster DJ (1981) The supply and accumulation of silica in the marine environment. Geochim Cosmochim Acta 45: 1715-1732

DeMaster DJ (2002) The accumulation and cycling of biogenic silica in the Southern Ocean: revisiting the marine silica budget. Deep-Sea Res II 49:3155-3167

DeMaster DJ, McKee BA, Nittrouer CA, Qian JG, Cheng GD (1985) Rates of sediment accumulation and particle reworking based on radiochemical measurements from continental shelf deposits in the East China Sea. Cont Shelf Res 4:143-158

DeMaster DJ, Ragueneau O, Nittrouer CA (1996) Preservation efficiencies and accumulation rates for biogenic silica and organic C, N, and P in high-latitude sediments: the Ross Sea. J Geophys Res 101(C8):18501-18518

Gao Y, Yu Q, Qi Y, Zhou J, Lu D, Li Y, Cheng C (2003) Species composition and ecological distribution of planktonic diatoms in the Changjiang River estuary during spring. Chin J Appl Ecol 14:1044-1048 (in Chinese with English abstract)

GEOHAB (2001) Global ecology and oceanography of harmful algal blooms, Science Plan. In: Glibert P, Pitcher G (eds) Report No. 1. Scientific Committee on Ocean Research (SCOR), Baltimore, MD, and Intergovernmental Oceanographic Commission (IOC), Paris

Gong GC, Chen YL, Liu KK (1996) Chemical hydrography and chlorophyll a distribution in the East China Sea in summer: implications in nutrient dynamics. Cont Shelf Res 16:1561-1590

Gong GC, Wen YH, Wang BW, Liu GJ (2003) Seasonal variation of chlorophyll a concentration, primary production and environmental conditions in the subtropical East China Sea. Deep-Sea Res II 50:1219-1236

Gupta GVM, Sarma VV (1997) Biogenic silica in the Bay of Bengal during the southwest monsoon. Oceanol Acta 20: 493-500

Han X, Wang X, Sun X, Shi X, Zhu C, Zhang C, Lu R (2003) Nutrient distribution and its relationship with occurrence of red tide in coastal area of East China Sea. Chin J Appl Ecol 14:1097-1101 (in Chinese with English abstract)

Heiskanen AS, Keck A (1996) Distribution and sinking rates of phytoplankton, detritus, and particulate biogenic silica in the Laptev Sea and Lena River (Arctic Siberia). Mar Chem 53:229-245

Huh CA, Su CC (1999) Sedimentation dynamics in the East China Sea elucidated from ${ }^{210} \mathrm{~Pb},{ }^{137} \mathrm{Cs}$ and ${ }^{239,240} \mathrm{Pu}$. Mar Geol 160:183-196
Ingall E, Jahnke R (1994) Evidence for enhanced phosphorus regeneration from marine sediments overlain by oxygen depleted waters. Geochim Cosmochim Acta 58:2571-2575

Iseki K, Okamura K, Kiyomoto Y (2003) Seasonality and composition of downward particulate fluxes at the continental shelf and Okinawa Trough in the East China Sea. DeepSea Res II 50:457-473

Kamatani A, Takano M (1984) The behavior of dissolved silica during the mixing of river and sea waters in Tokyo Bay. Estuar Coast Shelf Sci 19:505-512

Kim YL (1992) Marine geology of the East China Sea. China Ocean Press, Beijing (in Chinese)

Koning E, Brummer GJ, Raaphorst WV, Bennekom JV, Helder W, Iperen JV (1997) Settling, dissolution and burial of biogenic silica in the sediments off Somalia (northwestern Indian Ocean). Deep-Sea Res II 44:1341-1360

Lee HJ, Chao SY (2003) A climatological description of circulation in and around the East China Sea. Deep-Sea Res II 50:1065-1084

Li MT, Cheng HQ (2001) Changes of dissolved silicate flux from the Changjiang River into sea and its influence in the last 50 years. China Environ Sci 21:193-197 (in Chinese)

Li YH, Gregory S (1974) Diffusion of ions in sea water and in deep-sea sediments. Geochim Cosmochim Acta 38: 703-714

Lin K, Chen ZS, Guo BH, Tang YX (1999) Seasonal transport and exchange between the Kuroshio water and shelf water. In: Hu DX, Tsunogai S (eds) Margin flux in the East China Sea. China Ocean Press, Beijing, p 21-32

Liu KK, Tang TY, Gong GC, Chen LY, Shiah FK (2000) Crossshelf and along-shelf nutrient fluxes derived from flow fields and chemical hydrography observed in the southern East China Sea off northern Taiwan. Cont Shelf Res 20:493-523

Liu SM, Ye XW, Zhang J, Zhao YF (2002) Problems with biogenic silica measurement in marginal seas. Mar Geol 192: 383-392

Liu SM, Zhang J, Chen HT, Wu Y, Xiong H, Zhang ZF (2003a) Nutrients in the Changjiang and its tributaries. Biogeochemistry 62:1-18

Liu SM, Zhang J, Jiang WS (2003b) Pore water nutrient regeneration in shallow coastal Bohai Sea, China. J Oceanogr 59:377-385

Liu SM, Zhang J, Chen SZ, Chen HT, Hong GH, Wei H, Wu QM (2003c) Inventory of nutrient compounds in the Yellow Sea. Cont Shelf Res 23:1161-1174

Morgan E (1991) Chemometrics: experimental design — analytical chemistry by open learning. John Wiley \& Sons, Chichester

Mortlock RA, Froelich PN (1989) A simple method for the rapid determination of biogenic opal in pelagic marine sediments. Deep-Sea Res 36:1415-1426

Nelson DM, Goering JJ (1978) Assimilation of silicic acid by phytoplankton in the Baja California and the northwest Africa upwelling systems. Limnol Oceanogr 23:508-517

Nelson DM, DeMaster DJ, Dunbar RB, Smith WO (1996) Cycling of organic carbon and biogenic silica in the Southern Ocean: estimates of water-column and sedimentary fluxes on the Ross Sea continental shelf. J Geophys Res 101(C8):18519-18532

Nelson DM, Brzezinski MA, Sigmon DE, Franck VM (2001) A seasonal progression of Si limitation in the Pacific sector of the Southern Ocean. Deep-Sea Res II 48:3973-3995

Nelson DM, Anderson RF, Barber RT, Brzezinski MA and 12 others (2002) Vertical budgets for organic carbon and biogenic silica in the Pacific sector of the Southern Ocean, 1996-1998. Deep-Sea Res II 49:1645-1674

Oguri K, Matsumoto E, Yamada M, Saito Y, Iseki K (2003) Sed- 
iment accumulation rates and budgets of depositing particles of the East China Sea. Deep-Sea Res II 50:513-528

Pondaven P, Ruiz-Pino D, Druon JN, Fravalo C, Tréguer P (1999) Factors controlling silicon and nitrogen biogeochemical cycles in high nutrient, low chlorophyll systems (the Southern Ocean and the North Pacific): comparison with a mesotrophic system (the North Atlantic). Deep-Sea Res I 46:1923-1968

Pondaven P, Ragueneau O, Tréguer P, Hauvespre A, Dezileau L, Reyss JL (2000) Resolving the 'opal paradox' in the Southern Ocean. Nature 405:168-172

Rabouille C, Gaillard JF, Tréguer P, Vincendeau MA (1997) Biogenic silica recycling in surficial sediments across the Polar Front of the Southern Ocean (Indian Sector). DeepSea Res II 44:1151-1176

Ragueneau O, Varela EDB, Tréguer P, Quéguiner B, Amo YD (1994) Phytoplankton dynamics in relation to the biogeochemical cycle of silicon in a coastal ecosystem of Western Europe. Mar Ecol Prog Ser 106:157-172

Ragueneau O, Tréguer P, Anderson RF, Brzezinski MA and 11 others (2000) A review of the Si cycle in the modern ocean: recent progress and missing gaps in the application of biogenic opal as a paleoproxy. Global Planet Change 543:315-366

Ragueneau O, Gallinari M, Corrin L, Grandel S and 7 others (2001) The benthic silica cycle in the Northeast Atlantic: annual mass balance, seasonality, and importance of nonsteady-state processes for the early diagenesis of biogenic opal in deep-sea sediments. Prog Oceanogr 50:171-200

Ren JL, Zhang J, Luo JQ, Pei XK, Jiang ZX (2001) Improved fluorimetric determination of dissolved aluminium by micelle-enhanced lumogallion complex in natural waters. The Analyst 126:698-702

Romero O, Hebbeln D (2003) Biogenic silica and diatom thanatocoenosis in surface sediments below the Peru-Chile Current: controlling mechanisms and relationship with productivity of surface waters. Mar Micropaleontol 48:71-90

Schlüter M, Sauter E (2000) Biogenic silica cycle in surface sediments of the Greenland Sea. J Mar Syst 23:333-342

Schlüter M, Rutgers van der Loeff MM, Holby O, Kuhn G (1998) Silica cycle in surface sediments of the South

Editorial responsibility: Otto Kinne (Editor-in-Chief), Oldendorf/Luhe, Germany
Atlantic. Deep-Sea Res I 45:1085-1109

Srithongouthai S, Sonoyama YI, Tada K, Montani S (2003) The influence of environmental variability on silicate exchange rates between sediment and water in a shallowwater coastal ecosystem, the Seto Inland Sea, Japan. Mar Pollut Bull 47:10-17

Tréguer P, Pondaven P (2000) Global change: silica control of carbon dioxide. Nature 406:358-359

Tréguer P, Nelson DM, Van Bennekom AJ, DeMaster DJ, Leynaert A, Quéguiner B (1995) The silica balance in the world ocean: a reestimate. Science 268:375-379

Turner RE, Rabalais NN (1994) Coastal eutrophication near the Mississippi river delta. Nature 368:619-621

Ullman WJ, Aller RC (1982) Diffusion coefficients in nearshore marine sediments. Limnol Oceanogr 27:552-556

Vanderborght JP, Wollast R, Billen G (1977a) Kinetic models of diagenesis in disturbed sediments. Part 1. Mass transfer properties and silica diagenesis. Limnol Oceanogr 22: 787-793

Vanderborght JP, Wollast R, Billen G (1977b) Kinetic models of diagenesis in disturbed sediments. Part 2. Nitrogen diagenesis. Limnol Oceanogr 22:794-803

Wang JH, Huang XQ (2003) Ecological characteristics of Prorocentrum dentatum and the cause of harmful algal bloom formation in China Sea. Chin J Appl Ecol 14:1065-1069 (in Chinese with English abstract)

Wang SL, Chen CTA, Hong GH, Chung CS (2000) Carbon dioxide and related parameters in the East China Sea. Cont Shelf Res 20:525-544

Zhou W, Huo W, Yuan X, Yin K (2003) Distribution features of chlorophyll a and primary productivity in high frequency area of red tide in East China Sea during spring. Chin J Appl Ecol 14:1055-1059 (in Chinese with English abstract)

Zhu G, Xu W, Zhu D, Shi Q, Zhang J (2003) Distribution of phytoplankton and water dynamical environmental factors in high red tide occurrence area of Changjiang River estuary. Chin J Appl Ecol 14:1135-1139 (in Chinese with English abstract)

Zhu M, Li R, Mu X, Ji R (1997) Harmful algal blooms in China seas. Ocean Res Spec Issue 19:173-184

Submitted: December 2, 2003; Accepted: December 21, 2004 Proofs received from author(s): March 12, 2005 